\title{
STUDIES ON BEACH SAND WITH ADDITIVES IN WARM MIX
}

\section{ASPHALT}

\author{
Basavaraj M Rajoor ${ }^{1}$, Pradeep Maisnam ${ }^{2}$ \\ ${ }^{1}$ Assistant Professor, Department of Civil Engineering, Global Academy of Technology, Bengaluru, Karnataka, India \\ ${ }^{2}$ MTech Student, Department of Civil Engineering, BMSCE, Bengaluru, Karnataka, India
}

\begin{abstract}
The properties of Asphalt and Asphalt mixes can be improved to meet the requirement of pavement with the incorporations of certain additives or a blend of additives which are known as Asphalt modifiers. This is expected to give higher life of surfacing depending upon degree of modifications and types of additives, trial test studies. These Asphalt modifiers are like natural rubber, crumb rubber, waste plastic, and some polymers like polyethylene, ethylene vinyl acetate, and styrene-butadiene-styrene. This report deals with the properties of bituminous mixes can be improved further with the addition of chemical additives like Sasobit in varying percentages. The main objective is to study the stability of bituminous mixes by partial replacement of dust by Beach Sand in varying percentages by carrying out Marshall Stability Test and to study the performance of indirect tensile strength and fatigue life of the bituminous mixes. It is shown that the stability of the mixes without replacement of dust by beach sand has good performance when compared with replaced specimens.
\end{abstract}

Keywords: Warm Mix Asphalt, Beach Sand, Crumb Rubber Modified Bitumen, Marshal Stability, Indirect Tensile Test, Fatigue.

\section{INTRODUCTION}

Warm-Mix Asphalt (WMA) technology, which has been gaining popularity in recent years, is used to reduce the mixing and compaction temperatures of asphalt mixtures, improve the working conditions at site, and minimize the effect on the environment.

The properties of the bituminous mix can be enhanced by adding additives like Sasobit, zycotherm, etc. Sasobit are fine crystalline long chain aliphatic hydrocarbon and also known as wax, not the wax that is naturally found in liquid asphalt. Its melting point lies between $85-1150 \mathrm{C}$ and is completely soluble in asphalt at temperatures above 115oC.Sasobitis a Fischer-Tropsch wax with a high melting point. Sasobit WMA technology has been widely used worldwide. Sasobit is described as an asphalt flow improver because of its ability to lower the viscosity of the asphalt binder both during the asphalt mixing process and during laydown operations.

\subsection{Need for Modified Bitumen}

Bitumen is extensively used in flexible pavement construction for its properties such as inherent cohesive nature; weather resistant properties and also in case of processing in the molten state as in water proof coatings, sealed and binders. Binder is exposed to wide range of temperature and different loading conditions.
For road constructions, the industrial wastes that can be used as an alternative material are:

a) Crumb Rubber

b) Natural Rubber

c) Polymers

d) Waste Plastic Bags.

The addition of the above materials to partially replaced bitumen up to a little extent will improve some of the desirable properties of the mixes. These materials are known as Modifiers. The bitumen is then called Modified Bitumen.

\subsection{Summary of Benefits of Crumb Rubber}

The pavement with crumb rubber bituminous mix will have following results:

Improvement in durability of the pavement.

i. Due to higher elasticity and binder contents, there will be improvement in resistance to surface initiated and reflection cracking.

ii. Reduction in temperature susceptibility.

iii. Due to thicker binder films and anti-oxidants in the rubber tire, the aging and oxidation resistance will be improved.

iv. Due to higher viscosity, softening points and more elastic binder at high temperature, resistance to rutting i.e. pavement performance will be improved.

\subsection{Objectives of the Study}

$>$ To study the effect of CRMB for warm mix asphalts using beach sand as a replacement to fine material in bituminous mixes. 
To conduct the Marshall Test on Crumb Rubber Modified Bituminous mix before and after partial replacement of dust by beach sand in varying percentage at $20 \%, 40 \%, 60 \%, 80 \%$ and $100 \%$ for determining the Optimum binder content.

$>$ To conduct the Marshall Test on Crumb Rubber Modified Bituminous mix before and after replacement with $\mathrm{OBC}$ by the addition of additives viz. Sasobit and Zycotherm.

$>$ To conduct the Indirect Tensile Strength Test on Crumb Rubber Modified Bituminous mix before and after replacement of dust by beach sand with OBC by the addition of additives.

$>$ To conduct the Fatigue Test on Crumb Rubber Modified Bituminous mix before and after replacement of dust by beach sand with $\mathrm{OBC}$ by the addition of additives.

To compare the experimental results of Crumb Rubber Modified Bituminous mix between before and after replacement of dust by beach sand.

\subsection{Scope of the Present Study}

Bituminous concrete mix for Grade-II satisfying the requirement as per MoRTH (V Revision) specifications; and Crumb Rubber Modified Bituminous mix satisfying IRC:SP:53-2002 specification were selected for conducting Marshall Test, Indirect Tensile Strength and Fatigue Tests.
Marshall Test, Indirect Tensile Strength and Fatigue Tests were conducted to assess the performance of Crumb Rubber Modified Bituminous mix before and after replacement of dust by beach sand in varying percentages using additives. A load is applied to the CRMB Marshall specimen to determine Stability and Marshall Parameters. The stress level of the CRMB Marshall specimen is determined using Indirect Tensile Strength Test. And, the fatigue life of the CRMB mix is determined.

The experimental test results are analyzed to draw a comparison between the CRMB mix before and after replacement of dust by beach sand.

\section{PRESENT INVESTIGATIONS}

\subsection{General}

In the present study, the Marshall Parameter, Indirect Tensile Strength and Fatigue Test were conducted on Crumb Rubber Modified Bituminous Mix to study the behavior of the mixes after determination of Optimum Binder Content before and after replacement of dust by beach sand with additives viz. Sasobit and Zycotherm. The detailed information of the materials used and their properties are included in this unit. All the methods and the tests are carried out as per the IS specifications. The laboratory investigations to be carried out are shown in the flow chart below.

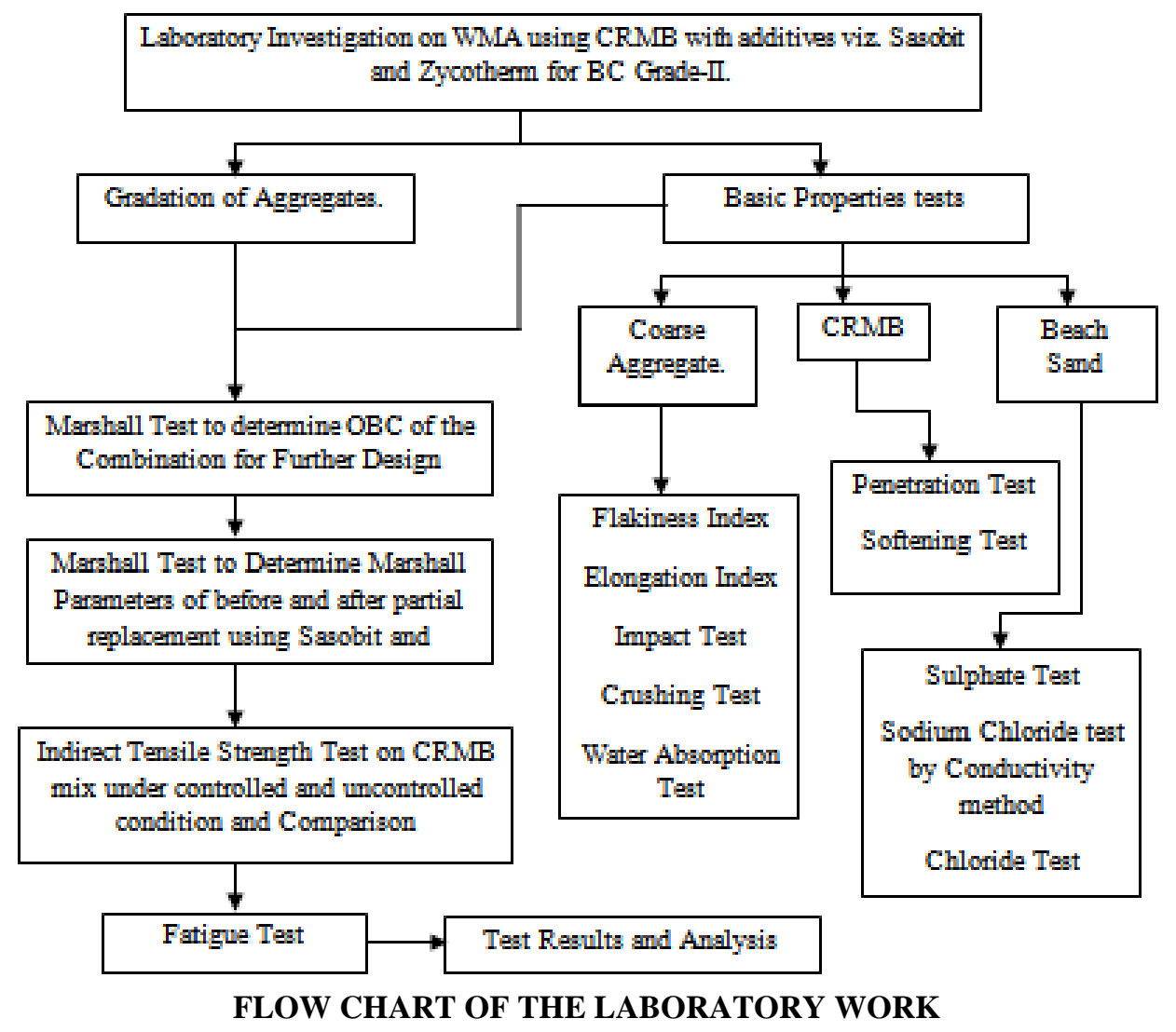




\subsection{Materials Used}

\section{Aggregates:}

The aggregate tests are conducted to meet their suitability satisfying the MoRTH Specifications (V-Revision) requirement for preparing Bituminous Mix Grade-II.

\section{Binder:}

Crumb Rubber Modified Bitumen is used as a binder for the preparation of the mix. Crumb Rubber Modified Bitumen test results satisfies the requirement as per IRC:SP:53-2002 guidelines.

Beach Sand:

The beach Sand which was collected from three different location viz, Suratkal, Mangalore; Karwar and Murdeshwar are tested for Sulphate content, Sodium Chloride and Chlorine to determine the salinity content in the beach sand. Out of these three locations, Suratkal Beach Sand has the lowest saline content and the Beach Sand of this location is selected for replacement of dust by varying percentage in Marshall Stability test.

Marshall Method of Crumb Rubber Modified Bituminous Mix Design:

The crumb rubber bituminous mixes are designed. The Optimum Binder Content (OBC) is determined for the mixes before and after replacement of dust by beach Sand with varying percentage as $20 \%, 40 \%, 60 \%, 80 \%$ and $100 \%$ of beach sand for further design.

The Marshall Test is carried out on the mixes before and after replacement of dust by beach Sand with additives for determining Marshall Parameters.

Indirect Tensile Strength for Crumb Rubber Modified Bituminous Mix Design:

The Indirect Tensile Strength Tests are conducted on Crumb Rubber Modified Bituminous mix before and after replacement of dust by beach Sand with additives under controlled and uncontrolled conditions.

Fatigue Test for Crumb Rubber Modified Bituminous Mix Design:

The Fatigue test is carried out on the Crumb Rubber Modified Bituminous mixes before and after replacement of dust by beach sand with additives.

Table 2.1: Properties of aggregate

\begin{tabular}{|l|l|l|}
\hline $\begin{array}{l}\text { Name of the } \\
\text { Tests }\end{array}$ & $\begin{array}{l}\text { Aggregate } \\
\text { Tests Value }\end{array}$ & $\begin{array}{l}\text { Requirements as per } \\
\text { Table MORTH } \\
\text { Specifications }\end{array}$ \\
\hline $\begin{array}{l}\text { Combined } \\
\text { Flakiness } \\
\begin{array}{l}\text { Elongation } \\
\text { Index }\end{array}\end{array}$ & $26.22 \%$ & Max 35\% \\
\hline Impact Value & $17.28 \%$ & Max 24\% \\
\hline $\begin{array}{l}\text { Crushing } \\
\text { Value }\end{array}$ & $17.44 \%$ & Max 30\% \\
\hline $\begin{array}{l}\text { Water } \\
\text { Absorption }\end{array}$ & $0.55 \%$ & Max 2\% \\
\hline
\end{tabular}

Table 2.2: specific gravity of materials

\begin{tabular}{|l|l|l|}
\hline $\begin{array}{l}\text { Sl. } \\
\text { No }\end{array}$ & Materials & Specific Gravity \\
\hline 1. & $\begin{array}{l}\text { Aggregate Passing 19mm IS } \\
\text { Sieve }\end{array}$ & 2.62 \\
\hline 2. & $\begin{array}{l}\text { Aggregate Passing 13.2mm } \\
\text { IS Sieve }\end{array}$ & 2.63 \\
\hline 3. & $\begin{array}{l}\text { Aggregate Passing 6mm IS } \\
\text { Sieve }\end{array}$ & 2.65 \\
\hline 4. & Dust & 2.67 \\
\hline
\end{tabular}

Table 2.3: Properties of CRMB

\begin{tabular}{|l|l|l|l|}
\hline Sl. No. & $\begin{array}{l}\text { Name of the } \\
\text { Test }\end{array}$ & $\begin{array}{l}\text { Tests } \\
\text { Results }\end{array}$ & $\begin{array}{l}\text { CRMB } \\
\text { RANGE }\end{array}$ \\
\hline 1. & $\begin{array}{l}\text { Penetration at } \\
25^{\circ} \mathrm{C}\end{array}$ & 54 & $50-60$ \\
\hline 2. & Softening Point & 53.5 & 55 \\
\hline
\end{tabular}

From the above table no 3 , the grade of CRMB is 55

Table 2.4: Test on Beach Sand (Suratkal, Mangalore

\begin{tabular}{|l|l|l|}
\hline Sl. No & Name of the Test & Results \\
\hline 1. & Sulphate & $3899.746 \mathrm{mg} / \mathrm{l}$ \\
\hline 2. & $\begin{array}{l}\text { Sodium Chloride by } \\
\text { conductivity method }\end{array}$ & $\begin{array}{l}\mathrm{Ec}=0.614 ; \text { and } \\
\text { Tds }=0.400\end{array}$ \\
\hline 3. & Chloride & $95.96 \mathrm{mg} / 1$ \\
\hline
\end{tabular}

Gradation of Aggregates:

(Grade-II) of the aggregates as per MoRTH specifications (V-Revision) and the obtained gradation are given in the following table.

Table2. 5: Gradation of the aggregates

\begin{tabular}{|l|l|l|l|l|}
\hline \multirow{2}{*}{$\begin{array}{l}\text { Sieve } \\
\text { size } \\
(\mathbf{m m})\end{array}$} & $\mathbf{2 0 \mathbf { m m }}$ & $\mathbf{1 2} \mathbf{~ m m}$ & $\mathbf{6} \mathbf{~ m m}$ & Dust \\
\cline { 2 - 5 } & passing & $\begin{array}{l}\text { \% } \\
\text { passing }\end{array}$ & $\begin{array}{l}\text { \% } \\
\text { passing }\end{array}$ & $\begin{array}{l}\text { \% } \\
\text { passing }\end{array}$ \\
\hline 19 & 100 & 100 & 100 & 100 \\
\hline 13.2 & 75.5 & 100 & 100 & 100 \\
\hline 9.5 & 1.5 & 100 & 100 & 100 \\
\hline 4.75 & & 48.8 & 100 & 100 \\
\hline 2.36 & & 7.6 & 78 & 100 \\
\hline 1.18 & & 0.5 & 45 & 95 \\
\hline 0.6 & & & 27.6 & 76 \\
\hline 0.3 & & & 23.4 & 58.6 \\
\hline 0.15 & & & 14 & 45.6 \\
\hline 0.075 & & & 4 & 11 \\
\hline
\end{tabular}




\begin{tabular}{|l|l|l|l|l|}
\hline $\begin{array}{l}\text { desired } \\
\text { gradation }\end{array}$ & $\begin{array}{l}\text { lower } \\
\text { limit }\end{array}$ & $\begin{array}{l}\text { upper } \\
\text { limit }\end{array}$ & $\begin{array}{l}\text { avg } \\
\text { limit }\end{array}$ & $\begin{array}{l}\text { obtained } \\
\text { gradation }\end{array}$ \\
\hline 100.00 & 100 & 100 & 100 & 100 \\
\hline 79 to 100 & 79 & 100 & 89.5 & 93.875 \\
\hline 70 to 88 & 70 & 88 & 79 & 75.375 \\
\hline 53 to 71 & 53 & 71 & 62 & 63.224 \\
\hline 42 to 58 & 42 & 58 & 50 & 48.688 \\
\hline 34 to 48 & 34 & 48 & 41 & 38.015 \\
\hline 26 to 38 & 26 & 38 & 32 & 28.388 \\
\hline 18 to 28 & 18 & 28 & 23 & 22.376 \\
\hline 12 to 20 & 12 & 20 & 16 & 16.444 \\
\hline 4 to 10 & 4 & 10 & 7 & 4.11 \\
\hline
\end{tabular}

\section{Test Results}

\begin{tabular}{|l|l|l|}
\hline $\begin{array}{l}\text { \% Combination of } \\
\text { Beach Sand }\end{array}$ & $\begin{array}{l}\text { Optimum } \\
\text { Binder } \\
\text { Content }\end{array}$ & Stability \\
\hline 0 & 5.9 & 2230 \\
\hline 20 & 5.85 & 1960 \\
\hline 40 & 5.95 & 2025 \\
\hline 60 & 5.7 & 2120 \\
\hline 80 & 5.5 & 1760 \\
\hline 100 & 5.85 & 1240 \\
\hline
\end{tabular}

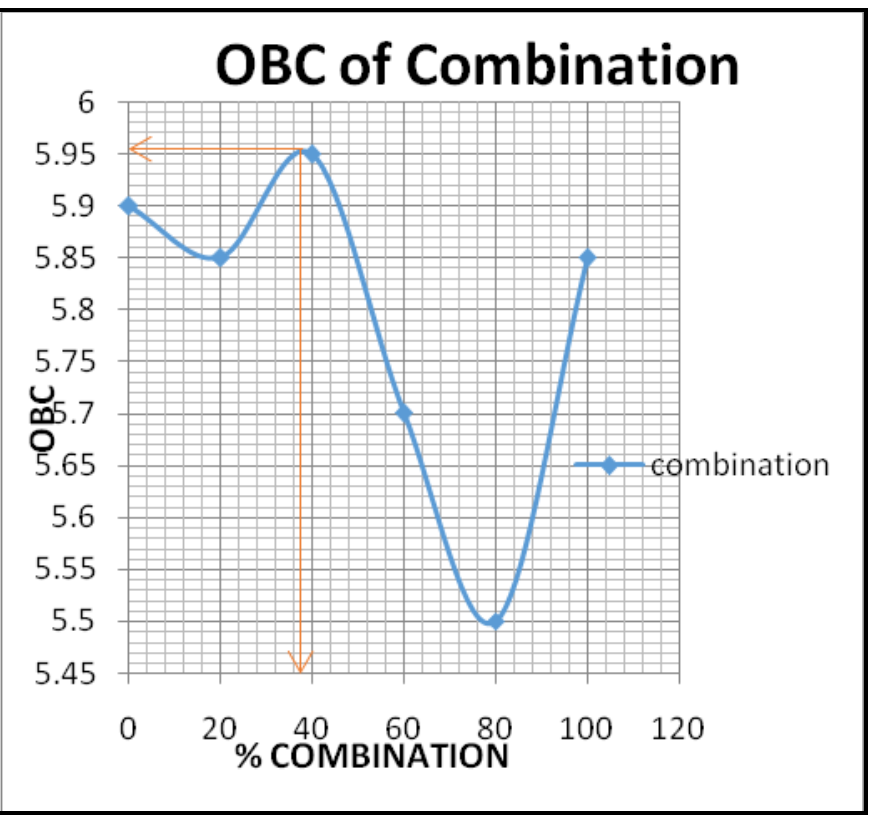

Graph to determine the OBC of the combination

A graph has been plotted between $\mathrm{OBC}$ and percentage combination of dust and beach sand to determined OBC of combination for further design of Crumb Rubber Modified Bituminous mix after replacement.

From graph it is observed that, at $40 \%$ replacement of dust by beach sand, the maximum $\mathrm{OBC}$ is obtained with $5.95 \%$. Hence, for the further design of Crumb Rubber Modified Bituminous mixes for partially replaced dust by beach sand, the same $\mathrm{OBC}$ and percentage combination is used.

\section{ANALYSIS OF TEST RESULTS}

\subsection{Marshall Parameters Results}

The bituminous pavement is subjected to traffic loading and so the maximum stability that a pavement can bear is needed to be determined. Hence, the Marshall Parameters of the Crumb Rubber Modified Bituminous Mix before and after partial replacement with additives viz. Sasobit and Zycotherm are analyzed.

The Marshall Test on Crumb Rubber Modified Bituminous mix before and after partial replacement of dust by beach sand in varying percentage at $20 \%, 40 \%, 60 \%, 80 \%$ and $100 \%$ with Sasobit (both normal condition and molten condition) and zycotherm as an additive. The Marshall parameters are analysed and then compared between the before and after partial replacement of dust by beach sand with the addition of additives.

Comparison b/w Marshall Parameters before and after partial replacement with the addition of additives

The Marshall Parameters of the CRMB mix before and after partial replacement with the addition of additives viz. Sasobit (both in normal and molten condition) and Zycotherm are compared and shown in the graph below with the table as reference.

Comparison of stability before replacement with addition of Sasobit in normal and molten condition

NORMAL WITHOUT REPLACEMENT

\begin{tabular}{|c|c|c|c|c|}
\hline \% Additives & Stability & $\begin{array}{l}\text { Avg } \\
\text { Stability }\end{array}$ & Flow & $\begin{array}{l}\text { Avg } \\
\text { Flow }\end{array}$ \\
\hline $1.5 \%$ & 1950.0 & \multirow[t]{2}{*}{2025.0} & 4.0 & \multirow[t]{2}{*}{4.4} \\
\hline $1.5 \%$ & 2100.0 & & 4.8 & \\
\hline $2.0 \%$ & 2625.0 & \multirow[t]{2}{*}{2700.0} & 4.2 & \multirow[t]{2}{*}{4.4} \\
\hline $2.0 \%$ & 2775.0 & & 4.6 & \\
\hline $2.5 \%$ & 2737.5 & \multirow[t]{2}{*}{2793.8} & 5.0 & \multirow[t]{2}{*}{5.0} \\
\hline $2.5 \%$ & 2850.0 & & 4.9 & \\
\hline $3.0 \%$ & 2100.0 & \multirow[t]{2}{*}{2137.5} & 4.5 & \multirow[t]{2}{*}{4.3} \\
\hline $3.0 \%$ & 2175.0 & & 4.0 & \\
\hline $3.5 \%$ & 1725.0 & \multirow[t]{2}{*}{1762.5} & 4.6 & \multirow[t]{2}{*}{5.1} \\
\hline $3.5 \%$ & 1800.0 & & 5.5 & \\
\hline
\end{tabular}


MOLTEN WITHOUT REPLACEMENT:

\begin{tabular}{|c|c|c|c|c|}
\hline$\%$ Additives & Stability & $\begin{array}{l}\text { Avg } \\
\text { Stability }\end{array}$ & Flow & $\begin{array}{l}\text { Avg } \\
\text { Flow }\end{array}$ \\
\hline $1.5 \%$ & 1950.0 & \multirow[t]{2}{*}{1931.3} & 4.0 & \multirow[t]{2}{*}{4.4} \\
\hline $1.5 \%$ & 1912.5 & & 4.8 & \\
\hline $2.0 \%$ & 2587.5 & \multirow[t]{2}{*}{2606.3} & 4.2 & \multirow[t]{2}{*}{4.4} \\
\hline $2.0 \%$ & 2625.0 & & 4.6 & \\
\hline $2.5 \%$ & 2737.5 & \multirow[t]{2}{*}{2718.8} & 5.0 & \multirow[t]{2}{*}{5.0} \\
\hline $2.5 \%$ & 2700.0 & & 4.9 & \\
\hline $3.0 \%$ & 2362.5 & \multirow[t]{2}{*}{2306.3} & 4.5 & \multirow[t]{2}{*}{4.3} \\
\hline $3.0 \%$ & 2250.0 & & 4.0 & \\
\hline $3.5 \%$ & 1500.0 & \multirow[t]{2}{*}{1575.0} & 4.6 & \multirow[t]{2}{*}{5.1} \\
\hline $3.5 \%$ & 1650.0 & & 5.5 & \\
\hline
\end{tabular}

Comparison of stability after partial replacement with addition of Sasobit in normal and molten condition

\begin{tabular}{|c|c|c|c|}
\hline \multicolumn{4}{|c|}{ NORMAL ADDITION } \\
\hline Stability & $\begin{array}{l}\text { Avg } \\
\text { Stability }\end{array}$ & Flow & Avg Flow \\
\hline 1672.50 & \multirow{2}{*}{1698.75} & 4.60 & \multirow{2}{*}{4.70} \\
\hline 1725.00 & & 4.80 & \\
\hline 2287.50 & \multirow{2}{*}{2298.75} & 4.20 & \multirow{2}{*}{4.40} \\
\hline 2310.00 & & 4.60 & \\
\hline 2550.00 & \multirow{2}{*}{2523.75} & 5.50 & \multirow{2}{*}{5.20} \\
\hline 2497.50 & & 4.90 & \\
\hline 2625.00 & \multirow{2}{*}{2662.50} & 5.20 & \multirow{2}{*}{5.10} \\
\hline 2700.00 & & 5.00 & \\
\hline 2175.00 & 2212.50 & 6.00 & 5.75 \\
\hline
\end{tabular}

\begin{tabular}{|l|l|l|l|}
\hline \multicolumn{3}{|l}{ MOLTEN ADDITION } \\
\hline \multirow{2}{*}{ Stability } & $\begin{array}{l}\text { Avg } \\
\text { Stability }\end{array}$ & Flow & $\begin{array}{l}\text { Avg } \\
\text { Flow }\end{array}$ \\
\hline 1875.0 & 1837.50 & 5.30 & \multirow{2}{*}{5.15} \\
\hline 1800.0 & & 5.00 & \\
\hline 1897.5 & \multirow{2}{*}{1923.75} & 4.60 & \multirow{2}{*}{4.90} \\
1950.0 & & 5.20 & \\
\hline 2250.0 & \multirow{2}{*}{2287.50} & 5.30 & \multirow{2}{*}{5.05} \\
2325.0 & \multirow{2}{*}{2531.25} & 5.80 & \\
\hline 2550.0 & & 5.20 & \multirow{2}{*}{5.35} \\
\hline 2512.5 & \multirow{2}{*}{1950.00} & 5.40 & \multirow{2}{*}{5.15} \\
\cline { 3 - 4 } & & 4.90 & \\
\hline 2025.0 & & &
\end{tabular}

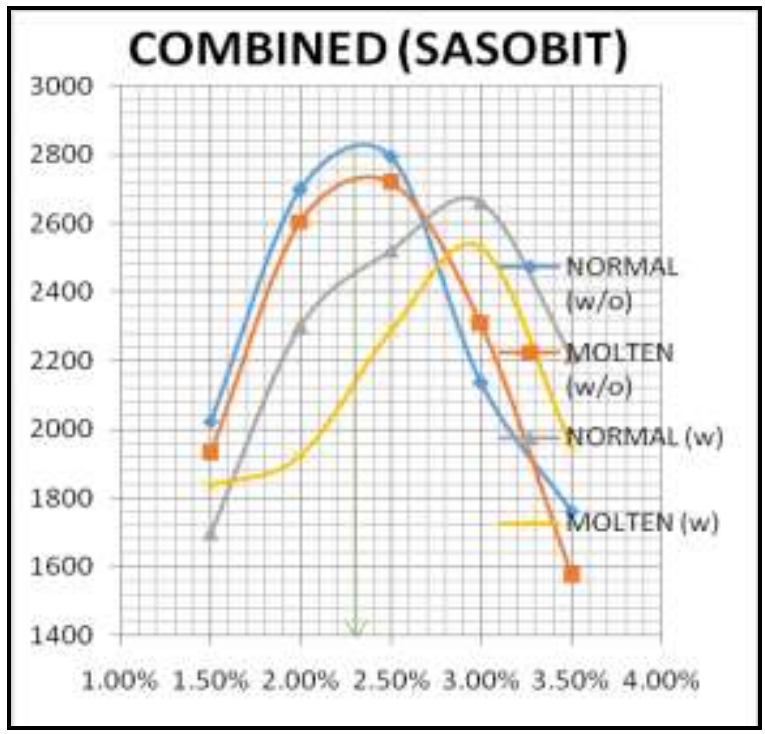

Above graph represents the Combined stability graph for before and after partial replacement of dust by beach sand with the addition of Sasobit in both normal and molten condition addition.

From the above graph plotted between before and partial replacement with the addition of Sasobit in different methods, it is found that the CRMB mix before replacement with the addition of Sasobit in normal condition with $2.35 \%$ shows good stability among CRMB mixes.

Moreover, the addition of Sasobit in CRMB mixes without replacement shows good Stability as compared with the mixes after partial replacement.

Comparison of stability between before and after partial replacement with addition of Zycotherm

Before replacement

\begin{tabular}{|l|l|l|l|}
\hline STABILITY & $\begin{array}{l}\text { AVG } \\
\text { STABILITY }\end{array}$ & FLOW & $\begin{array}{l}\text { AVG } \\
\text { FLOW }\end{array}$ \\
\hline 2662.5 & 2625 & 5 & 5.2 \\
\hline 2587.5 & & 5.4 & \\
\hline 2587.5 & 2700 & 4.9 & 5.35 \\
\hline 2812.5 & & 5.8 & \\
\hline 2287.5 & 2250 & 5.6 & 5.7 \\
\hline 2212.5 & & 5.8 & \\
\hline
\end{tabular}

After replacement

\begin{tabular}{|l|l|l|l|}
\hline STABILITY & $\begin{array}{l}\text { AVG } \\
\text { STABILITY }\end{array}$ & FLOW & $\begin{array}{l}\text { AVG } \\
\text { FLOW }\end{array}$ \\
\hline 2475 & 2550 & 5.4 & 5.2 \\
\hline 2625 & & 5 & \\
\hline 2550 & 2587.5 & 5.8 & 5.9 \\
\hline 2625 & & 6 & \\
\hline 2212.5 & 2325 & 5.4 & 5.85 \\
\hline 2437.5 & & 6.3 & \\
\hline
\end{tabular}




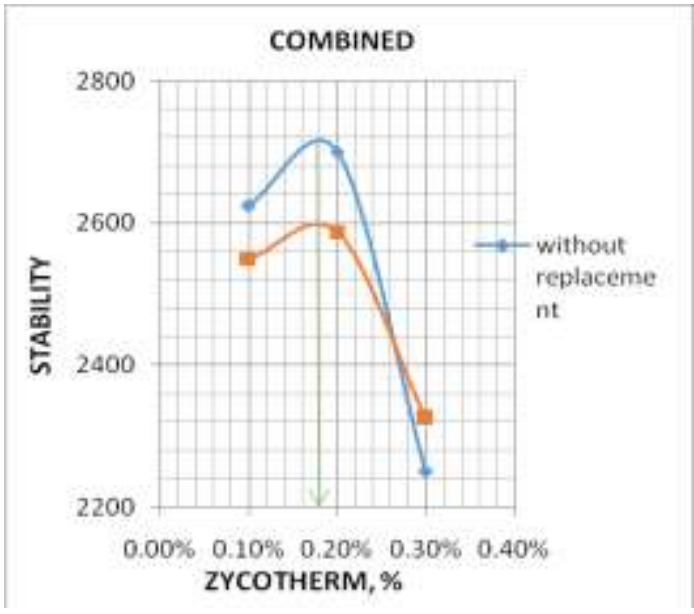

Combined stability graph for before and after partial replacement of dust by beach sand with the addition of Zycotherm.

From the above graph plotted with the addition of Zycotherm as an additive in CRMB mixes before and after partial replacement, it is observed that the CRMB mix before replacement is giving more stability than with partial replacement CRMB mix. The maximum stability is obtained with the addition of $0.18 \%$ of Zycotherm.

\subsection{Indirect Tensile Strength Test}

The performance of the bituminous paving mixes needs to be evaluated under various loading with controlled and uncontrolled condition as they are subjected to various applications of repeated traffic loads. Hence, Indirect Tensile Strength test is conducted on Marshall Specimen of Crumb Rubber Modified Bituminous Mixes before and after partial replacement of dust by beach sand with the addition of additives under controlled and uncontrolled condition.

The percentage of additive giving optimum stability obtained from Marshall Tests is used in this test. In case of Sasobit, addition in normal condition has shown more stability than that in molten condition in both before and after replacement. Hence, only Sasobit addition in normal condition of CRMB mix is used for this test.

\begin{tabular}{|l|l|l|}
\hline \multirow{2}{*}{$\begin{array}{l}\text { TYPE OF } \\
\text { ADDITIVES }\end{array}$} & \begin{tabular}{l} 
CONTROLLED CONDITION \\
\cline { 2 - 3 } \\
replacement
\end{tabular} & $\begin{array}{l}\text { After partial } \\
\text { replacement }\end{array}$ \\
\hline $\begin{array}{l}\text { SASOBIT in } \\
\text { Normal } \\
\text { addition }\end{array}$ & 10.57 & 9.20 \\
\hline ZYCOTHERM & 9.16 & 8.47 \\
\hline
\end{tabular}

\begin{tabular}{|l|l|l|}
\hline \multirow{2}{*}{$\begin{array}{l}\text { TYPE OF } \\
\text { ADDITIVES }\end{array}$} & \multicolumn{2}{|l|}{$\begin{array}{l}\text { UNCONTROLLED } \\
\text { CONDITION }\end{array}$} \\
\cline { 2 - 3 } & $\begin{array}{l}\text { Before } \\
\text { replacement }\end{array}$ & $\begin{array}{l}\text { After partial } \\
\text { replacement }\end{array}$ \\
\hline $\begin{array}{l}\text { SASOBIT in } \\
\text { Normal } \\
\text { addition }\end{array}$ & 8.97 & 7.49 \\
\hline ZYCOTHERM & 7.22 & 6.73 \\
\hline
\end{tabular}

The comparison between CRMB before and after partial replacement mixes for both the controlled and uncontrolled condition is shown in the table. The results obtained from ITS test show that the tensile strength under controlled condition is more than that of uncontrolled condition in both the before and after replacement of beach sand.

\subsection{Fatigue Test}

The performance of the bituminous paving mixes also needs to be evaluated by checking the fatigue life of specimen under loading condition till specimen is failed. Fatigue test is conducted on Marshall Specimen of Crumb Rubber Modified Bituminous Mixes before and after partial replacement of dust by beach sand with the addition of additives.

The percentage of additive showing optimum stability obtained from Marshall Tests is used in this test. In case of Sasobit, addition in normal condition has shown more stability than that in molten condition in both before and after replacement. Hence, only Sasobit addition in normal condition of CRMB mix is used for the fatigue test.

\begin{tabular}{|l|l|l|l|}
\hline & ADDITIVES & $\begin{array}{l}\text { \% of } \\
\text { Additives }\end{array}$ & $\begin{array}{l}\text { Fatigue } \\
\text { life } \\
\text { (Cycles) }\end{array}$ \\
\hline \multirow{2}{*}{$\begin{array}{l}\text { BEFORE } \\
\text { REPLACEMENT }\end{array}$} & $\begin{array}{l}\text { Sasobit } \\
\text { (Normal) }\end{array}$ & $2.35 \%$ & 1271 \\
\cline { 2 - 4 } & Zycotherm & $0.18 \%$ & 1873 \\
\hline
\end{tabular}

\begin{tabular}{|l|l|l|l|}
\hline & ADDITIVES & $\begin{array}{l}\% \text { of } \\
\text { Additives }\end{array}$ & $\begin{array}{l}\text { Fatigue } \\
\text { life } \\
\text { (Cycles) }\end{array}$ \\
\hline \multirow{2}{*}{$\begin{array}{l}\text { AFTER } \\
\text { REPLACEMENT }\end{array}$} & $\begin{array}{l}\text { Sasobit } \\
\text { (Normal) }\end{array}$ & $2.95 \%$ & 1063 \\
\cline { 2 - 4 } & Zycotherm & $0.18 \%$ & 982 \\
\hline
\end{tabular}

\section{DISCUSSIONS AND CONCLUSIONS}

\subsection{General}

The Crumb Rubber Modified Bituminous mix for Bituminous Concrete (Grade-II) was prepared with and without partial replacement of dust by beach sand in varying percentage such as $20 \%, 40 \%, 60 \%, 80 \%$ and $100 \%$ to determine the Optimum Binder Content for the combination of the partially replaced mixes. Additives such as Sasobit and Zycotherm are also used to enhance the properties of the mixes.

\subsection{Influence of Warm Mix Additives (SASOBIT \&} ZYCOTHERM) on Crumb Rubber Modified

\section{Bitumen}

The maximum $\mathrm{OBC}$ for the combination was obtained i.e. $5.95 \%$ at $40 \%$ replacement of dust by beach sand. Hence, using this OBC and 40\% replacement combination, Marshall Specimens are prepared with the addition of additives viz. Sasobit varying 1.5\%, 2.0\%, $2.5 \%, 3.0 \%$ and $3.5 \%$; and Zycotherm varying $0.1 \%, 0.2 \%$ and $0.3 \%$ for the 
partially replaced mixes. And, CRMB mix without replacement of beach sand with $5.9 \%$ OBC was also prepared using the same additives in same manner. It is found that the strength obtained is more than that of replaced mix.

\subsection{Influence of Warm Mix Additives (SASOBIT \& ZYCOTHERM) on Marshall Stability of Crumb}

\section{Rubber Modified Bituminous Mix}

The maximum stability with additives for mixes before and after replacement is determined by plotting a StabilityPercentages Additives graph together for both without and with replacement specimens

In both before and after partial replacement mixes, the addition of Sasobit in normal condition is giving higher stability than that of molten condition.

It is found in samples of without replaced CRMB mixes, maximum stability is obtained at $2.35 \%$ addition of Sasobit in both normal and molten condition. But, the obtained normal condition stability at $2.35 \%$ addition of Sasobit is more than that of molten condition addition.

For partially replaced CRMB mixes, maximum stability is obtained at $2.95 \%$ addition of Sasobit in both normal and molten condition. Similarly, the obtained normal condition stability at $2.95 \%$ addition of Sasobit is more than that of molten condition addition.

With the addition of Zycotherm, the maximum stability is obtained at $0.18 \%$ addition in both the before and after cases of partially replacement mixes by beach sand.

In both the case of Sasobit and Zycotherm addition, the CRMB mix before replacement of dust by beach sand shows higher stability than those partially replaced CRMB mixes.

\subsection{Influence of Warm Mix Additives (SASOBIT \& ZYCOTHERM) on Indirect Tensile Strength of}

\section{Crumb Rubber Modified Bituminous Mix}

The obtained percentage of Sasobit $(2.35 \%)$ and Zycotherm $(0.18 \%)$ in before replacement of dust by beach sand CRMB mix and obtained percentage of Sasobit (2.95\%) and Zycotherm $(0.18 \%)$ in after partial replacement of dust by beach sand CRMB mix in Marshall test are used for the further design of CRMB mixes for Indirect Tensile Strength (ITS) test for before and after partial replaced CRMB mixes respectively.

The tensile strength of the Crumb Rubber Modified Bituminous mixes was determined using Indirect Tensile Strength Tests for both before and after partial replacement of dust by beach sand under controlled and uncontrolled condition.
The results obtained from ITS test show that the tensile strength under controlled condition is giving more than that of uncontrolled condition in both the before and after replacement.

\subsection{Influence of Warm Mix Additives (SASOBIT \& ZYCOTHERM) on Fatigue life of Crumb Rubber}

\section{Modified Bituminous Mix}

The obtained percentage of Sasobit $(2.35 \%)$ and Zycotherm $(0.18 \%)$ in before replacement of dust by beach sand CRMB mix and obtained percentage of Sasobit (2.95\%) and Zycotherm $(0.18 \%)$ in after partial replacement of dust by beach sand CRMB mix in Marshall test are used in Fatigue test for before and after partial replaced CRMB mixes respectively.

The fatigue life of the Crumb Rubber Modified Bituminous mixes was determined using fatigue test for both before and after partial replacement of dust by beach sand.

The fatigue life for all types of CRMB mixes i.e. before and after partial replacement of dust by beach sand

The results obtained from fatigue test shows that the fatigue life of before replacement of dust by beach sand is showing good fatigue life than that of after replacement of dust by beach sand.

\section{CONCLUSION}

1) It was observed that the Marshall Parameters of the CRMB mixes were enhanced with the addition of additives for both before and after partial replacement of dust by beach sand.

2) The maximum stability was obtained at $2.35 \%$ and $2.95 \%$ of Sasobit addition in normal condition without and with partial replacement respectively when compared to the molten condition addition.

3) The CRMB mix after addition of additives viz. Sasobit and Zycotherm without partial replacement shows higher stability than that with partial replacement of dust by beach sand.

4) It was observed that from ITS test, the Tensile Strength of before replacement of dust by beach sand is more than that of after partial replacement of dust by beach sand in both the controlled and uncontrolled condition.

5) The Tensile Strength of the CRMB mix under controlled condition is more than that under uncontrolled condition. It was observed that from Fatigue test, the fatigue life of specimen with before replacement of dust by beach sand is more than that of after partial replacement of dust by beach sand. 


\section{REFERENCES}

[1] "Laboratory Evaluation of HMA and WMA in BC Layer" by Dr. Kiran Kumar, Revansiddappa M, Manjunath S, Arvind C and SurajPokalwar in 2014.

[2] "Laboratory Evaluation of Crumb Rubber Modified Asphalt Mixes" by S.K. Patil, K Sudhakar Reddy and B.B. Pandey in 2004.

[3] "Laboratory Evaluation of Sasobit-Modified WarmMix Asphalt for Alaskan Conditions" by Juanyu Liu, Stephan Sabounjian, Peng Li, Billy Connar and Bruce Brunette in 2011.

[4] "Workability of Sasobit Warm Mixture AsphaltbyGui-juan Zhao and Ping Guo in 2012.

[5] "TWG -Warm Mix Asphalt."ByJohn Shaw -Business Unit Manager; Asphalt Additive(2007), HuntValley, MD -December 12, 2007.

[6] "A Study on Marshall Stability of Warm Mix Asphalt using Zycotherm a Chemical Additive" by Rohith $N$ and $J$ Ranjithain July 2013.

[7] Zycotherm, Zydex.

[8] "The Effect Of Warm Mix Asphalt Additive (Sasobit) On Determination Of Optimum Bitumen Content" byFrag Ahmed Ma Kridan, Ahmad KamilArshad\&MohdYusof Abdul Rahman- 2011.

[9] "Laboratory investigation of compaction characteristics \& performance of WMA containing chemical additives"by Liantong Mo, Xun Li, Xing Fang, M.Huurman, Shaopeng Wu-2012.

[10] "Fracture and Tensile Characteristics of AsphaltRubber Concrete" by MustaqueHossain and EnamHoquein 1999.

[11] "Fatigue Behavior of Rubberized Asphalt Concrete Mixtures Containing Warm Asphalt Additives" by Feipeng Xiao, Wenbin Zhao and Serji N Amirkhanianin 2008.

[12] IRC SP 53-2002, "Guidelines on use of Polymer and Rubber Modified Bitumen in Road Construction."

[13] Highway Materials and Pavement Testing (Fifth Edition), Dr. S.K. Khanna ; Dr. C.E.G. Justo and Dr. A. Veeraragavan, Department of Civil Engineering. Ministry of Road Transports \& Highways (Fifth Revision), published by Indian Roads Congress.

\section{BIOGRAPHIES}

BASAVARAJ M RAJOOR, Assistant Professor, Department of Civil Engineering, Global Academy of Technology, Bengulure-560098

PRADEEP MAISNAM, Mtech Student, Department of Civil Engineering, BMSCE, Bengulure-560098 